\title{
SECOND LIFE: \\ A THREE-DIMENIONAL VIRTUAL WORLD FOR DEVELOPING THAI EFL LEARNERS' ENGLISH COMMUNICATION SKILLS
}

\author{
Hambalee JEHMA \\ ORCID: 0000-0001-9232-5029 \\ Prince of Songkla University International College \\ Prince of Songkla University \\ Songkhla, THAILAND
}

Received: 15/09/2019 Accepted: 12/06/2020

\begin{abstract}
This quasi-experimental research aims to investigate if applying the Second life, a virtual platform, in the English communication classroom is highly effective. Other factors such as the gender differences, the difference of majors of study, and the number of hours spent on computers were also investigated. The Second life has been employed as a research tool in the study for developing English as a foreign language undergraduate students' English communication skills. The samples of this study were 40 undergraduate students from two different majors, social sciences and science, divided into16 males and 24 females. They were studying English course at the university as a compulsory subject. The students took the TOEIC test as the pre-test before the semester starts. They were, then, asked to practice their English communication skills by typically interacting with the English contents, having discussion in the Second Life platform virtually outside of the classroom. After the TOEIC test was taken again at the end of the semester as the post-test and the data has been analyzed by t-test and ANOVA, the findings show that students with different backgrounds which were genders, fields of study, and hours of spending the computers have indifferent mean scores in their communication skills. It means all the students have developed their English communication skills. Applying the Second Life in English Communication classroom for EFL learners is highly recommended.
\end{abstract}

Keywords: English communication skills, Second life, Thai EFL learners, Virtual classroom.

\section{INTRODUCTION}

The rapid evolution of information and communication technology has a great influence on the societies and education. Particularly, educators in the field of language teaching or English teachers always make conscious and research effort to increase the effectiveness of their teaching approach. They have wholeheartedly tried to find any productive ways to make language learners enjoyable while they are learning the subject. Various activities, namely games, songs and interesting stories, have been integrated in the language classroom for ages. Nevertheless, when the technology like computers is launched to the market along with other useful programs like the internet, technology- enhanced education is becoming an increasingly important. Virtual platform like Second Life has recently been applied in teaching and learning, especially Second Life (SL). However, only handful of studies has investigated its effectiveness in enhancing English communication skills, specifically in the Thai context. The present study aims to address this gap by exploring the use of SL into the university English communication courses in a comprehensive university in Thailand. It hopes to contribute to the growing body of knowledge in the use of virtual platforms in language teaching and learning.

\section{OBJECTIVES OF THE STUDY}

The aim of this study is mainly to investigate if applying the Second life, a virtual platform, in the English communication classroom is highly effective. Other factors such as the gender differences, the difference of majors of study, and the number of hours spent on computers were also investigated. Within this perspective, the research objectives for this study are as follows: 
1. To investigate if there is significant development of EFL students' English communication skills learning through the Second Life virtual classroom.

2. To explore whether the gender differences, the different majors of study, and the number of hours spent on computers have any impacts on students' English communication skills development learning through the Second Life virtual classroom.

The two significant objectives mentioned earlier aim to answer the following two significant hypotheses:

1. The students' post-test scores will be greater than their pre-test scores at the level of significance.

2. The gender differences, the different majors of study, and the number of hours spent on computers have significant impacts on students' English communication skills development.

\section{LITERATURE REVIEW}

\section{Second Life for Education}

In 2003, the new interesting virtual world called "Second Life" has been released. This internet-based 3-dimensional virtual world has been created by Linden Labs Company in San Francisco. The total numbers of users around the world now has beaten the numbers of over 16 million registered users over the last few years (Linden Lab, 2009). Though there were other virtual reality environment such as Twinity (Metaversum GmbH, 2009), and There (Mekena Technologies, 2009) as the SL competitors, it was considered the most attractive virtual world as there were various interesting activities the users can enjoy compared to its competitors (Wagner, 2008). Avatar is called for the users' virtual representatives. The appearance of the users will be customized for their own avatars. So that the users can interact with each other through the avatar themselves. Moreover, the environment can be transformed by creating the virtual intended objects, together with communicate, collaborate and so on (Fetscherin and Lattemann, 2008). To view the content and travel around in the SL, users can control their own avatar by typically using the keyboards or mouse from the computer by moving it to the directions, left or right, or even flying by choosing the flying button shown on the screen (The Schome Community, 2007). The avatar themselves are called the "residents" of SL. They can easily communicate via chat by simply texting or voice communication via their connected microphones. Though the program itself seems to be advanced in terms of creating the program, it is the users' friendly program even the ones with no programming experiences. The mentioned reasons can affirm why the SL was rapidly widespread globally. That's why it brought the attention of the educators in applying this attractive and interesting program into their teaching and learning (Bainbridge, 2007). Though there are some limitation such as the high speed of the internet while being online required, its $3 \mathrm{D}$ social interaction and realistic visualization definitely concur the limitation is worth effort (Braman,Vincenti, Arboleda \& Jinman, 2009). Though becoming more interests in conduction the researches and studies concerning the SL is being subtle, the limited studies have been conducted concerning applying it into the classroom specifically for English language learning.

\section{Teaching and Learning English Communication Skills}

The English communication four skills, listening, speaking, writing, and reading are very important to both for education or business. That is the reason why so many language learners are very interested in improving these skills (Zhang, 2009). Because many of them aspire to professional careers in English dominant communities, the coming decade will see increasing pressure placed upon EFL high school, college, and university graduates to possess excellent skills in both speech and writing. EFL teachers commonly turn to widely accept a second language or a foreign language (L2) teaching methods and materials. Though a lot of materials supporting teaching L2 learners developing English communication skills, they seem not to be successful because of many reasons. Some of the students are required to study English in the classroom while being an undergraduate for their degree (Murphy, 1991). In addition to speaking, listening skills, receptive skills should be focused as it plays an important role in communication curricula because high school and college students are expected to enroll in lecture-centered courses during their earliest experiences within mainstream classrooms. Lecture-centered teaching in mainstream classrooms requires that EFL college students function effectively as listeners from the very beginning of their academic careers. 
Within most classroom settings, listening serves as a primary channel for learning while reading is also vital since the students are required to read for any lessons provided effectively. Moreover, the skill of reading comprehension has been ranked very important by the employers who will consider if they will employ the graduates in the future (Casner-Lotto \& Barrington, 2006). Because little attention is given to the students' listening abilities in other academic preparatory courses (Chamot, 1983), listening and connections between listening, speaking, and pronunciation emerge as central components of EFL oral communication (Murphy, 1991). To master this skill, not only the activities concerning listening skill solely, but the speaking tasks are required to be implemented since they both need to be together in order that L2 learners can master English oral communication skills (Zamel \& Sheikh Ibraham, 1985).

\section{Second Life for English Communication Classes}

Given the potentials of the second life in EFL classrooms, Hismanoglu (2012) investigated the future of second life as a new dimension in foreign language learning and teaching especially for the English communication classes. His paper aims to zoom in the benefits of using SL in foreign English Language classroom. He found out that SL provides a conducive learning environment to learners which teacher should make use of as either a main approach or a supplemental to their methodologies. Further, he noted that SL opens an avenue for students to enhance their own learning at their own pace while nurturing other communication skills like collaboration and sharing. SL, as he noted, assimilate a real-life language learning environment that made it effective language learning platform in terms of communication skills.

Understanding the learners' views in different countries are essential in implementing a new platform for learning. Although there were several works done to vouch its positivity, it is likewise significant to explore how other learners from different regions view SL. In 2012, Baram, Cukurbasi, Polak and Dogusoy took a step in looking into the potentials of second life in education through second life users' profiles and views. A total of 118 participants were involved in the study. Using a likert scale questionnaire, the study revealed that majority of the SL users did not have specific thoughts about the applicability of SL in education and are not willing to participate in any activity that involved it. Further, the view SL is not stretched to its potentials being an educational learning platform which is of opposition to many findings that considered it positive. Although there are quite a few who saw the positive side on it. It was revealed though that students' learning is quite positive when action learning principles were incorporated. This was evident on one of the responses of the participants which state that "SL makes me communicate better with people". The study then, concluded that SL may reduce learner-learner distance in e-learning in addition to reducing teacher-learner distance.

In a similar study, Brooks (2016) explored the use of second life as applied in teaching. In her article, she looked at the ways virtual world was employed within the traditional "brick and mortar" language classrooms and assessed its effectivity. The findings revealed that SL can be integrated in the language communication classroom in various ways and have shown effectiveness than other virtual platforms. Seeing the clear benefits of SL, it was recommended that quantitative approaches may be used in exploring its effectiveness particularly focus on the macro-skills, communication skills. Further, it was also noted that the design of SL is crucial to learners; thus, a creative design is necessary to ensure seamless learning.

Despite the negative outlook of students' perception on SL as an educational learning platform in Turkey, several studies continue to explore its potentials as a learning tool. Chiang, Yang, Huang and Liou (2014) investigated the impact of a 3D virtual learning environment based on Second Life on student motivation and achievement in learning English as a second language especially in English communication class. Twenty-one students, one English instructor and one tutor participated in their study. Using one-way ANOVA, the results revealed a positive influence on the participants' self-efficacy on English learning in 3D virtual worlds and its effectiveness in learning English communication. The study concluded that 3D virtual worlds provide situated learning environments and thematic learning scenarios, as well as socialization and interactive communication environments for students. Learners who have higher intrinsic goal orientation or higher extrinsic goal orientation of English communication learning in Second life or higher self-efficacy would have higher achievement. Thus, the paper shed positive light, a reverse view of the case of Turkey, on the potentials of SL in employing as learning platform in educational institutions. SL may demonstrate enhanced learning achievement among students. 
Ince et al. (2014) developed a 3-dimensional interactive multiuser and multi-admin IUVIRLAB featuring active learning methods and techniques for university students and to introduce the virtual laboratory of the Istanbul University and show its effects on students' attitudes on communication skills and its laboratory. Based on the study, students did not have any technical problems in using the 3-dimensional interactive tool. The study also demonstrated students' positive outlook at it and their high motivation in using the tool for learning. It was also noted that students were at ease using the tool and were convenient for learning.

As some researches support the effectiveness of SL in teaching, Hassan, Dzakiria and Idrus (2016) focused on students' perception. They intended to elicit Iraqi students' perception on SL's potential as a virtual platform to improve English communication learning. In carrying out their study, a qualitative case study was employed through interviews as their data collection technique. Based on the findings, the Iraqi students' showcase an affirmative response on the potentials of SL in enhancing their English language skills and proficiency through their interaction with the avatar which helped them reduce language anxiety and this making learning English more interesting.

One of the challenges that every foreign language learner is language anxiety especially for communication. It is what hampers the development of every learner's language skills. This means learners' perception of learning their target language has a huge impact in the success of their development. Looking at this perspective, Couto (2011) proposed a study to look at the impact of Second Life in learners' foreign language anxiety. Two stages were considered in carrying out the study; first was a native English speaker was paired with a native Spanish speaker to complete number of speaking activities; and the second was as same as the first, but it will have a randomly selected native Spanish speaker which was conducted in a university. After having performed the activities, participants were asked to answer a Foreign Language Classroom Anxiety Scale (FLCAS). The results have shown that using SL, foreign language anxiety was reduced; however, the study identified some areas of opportunities like low number of student participants and instruments were mainly about students' impression that will require more empirical approaches such as Galvic Skin response and heart monitoring to strengthen the research to arrive at more conceive results.

Lan and Lin (2016) investigated how mobile seamless technology like SL can be used to enhance the pragmatic competence of learners. Their study noted that contextual influence on FL/SL has been an important issue in SLA. In the same vein, learners' context affects learning and the amount of transfer which is vital in enhancing pragmatic competence. Through their study, they confirmed that active involvement play an important role in the success of social communication which suggests that a careful design of learning tests and timeliness are essential in making mobile seamless technology effective.

In a recent study, Wang (2012) explored another technology-enabled tool for enhancing oral English teaching strategies. Using descriptive analysis, her study revealed a positive attitude toward teaching strategies based in SPOC. Because of this development, six teaching strategies were suggested such as text guidance, video demonstration, PPT assisted learning, micro-lecture learning, self-testing and group work. These strategies may further inform the design of the proposed study employing SL framework.

The literatures cited show the potentials of Second Life as an educational learning platform. Wang et al. (2012) noted that SL showed positive impact to students as they have become highly motivated which Chiang et al. (2014) considered to be an important aspect in improving higher achievement. Hismanoglu (2010) reported that SL presented positive points as most learners see learning in a more authentic learning space for SL resembles that of a real-life experience. Because of the authentic learning space, students and teachers alike are able to reduce social distance which often creates a wall for learning. Baram et al. (2012), in their paper, mentioned that SL promotes an ease of learning. This then affirms that SL may be a viable educational learning space as Wang (2012) noted it complements teaching. Although there are number of positive points, it is equally important to look at how it can be implemented as Brooks (2016) asserted, design is critical to the learning of students. In doing this more conducive and effective, it may be relevant to subscribe to Wang's (2012) suggested teaching strategies that compliment learning such as text guidance, video demonstration, PPT assisted learning, micro-lecture learning, self-testing and group work. Thus, the proposed study provides an opportunity in developing a SL learning tool and explore on how it can enhance the English communication skills in the Thai classroom. The results of the study may offer two salient contribution: first, it can provide a new learning options, that is the SL-driven learning tool, which can also 
be used for more exploration on how it impacts both the teacher and students in the English as a Foreign Language Classroom; second, it will provide a different perspective on how SL is viewed, implemented and designed as informed by the Thai context.

\section{METHOD}

The study employed a quasi-experimental research design. It used the Test of English for International Communication (TOEIC) for the pre and posttest.

\section{Participants}

The study involved 40 Thai freshmen students who were studying the university required English course at a comprehensive university in Thailand. There were 16 males and 24 females studying in two categorized majors, 17 students from social studies and 23 students from science majors. In terms of the numbers of spending time on computers weekly, they were divided into three groups, which were 5-6 hours, 7-9 hours, and 20 hours or more. Talking about their English learning experiences, they all have been studying English since they were at the secondary and high school levels as compulsory subjects following the Thai education system requirement. All of them have passed the similar minimum English requirement admission examination for getting to the university. Because of their similar Englsih scores of the admission examination, they have been, then, placed in this course together. And they can be assumed that their English background was quite at the similar level.

\section{Data Collection Tools}

In collecting the data, the test of English for international communication (TOEIC) was used. TOEIC is considered as a world-wide standardized test for examining the English communicative skill levels which is universally popular as almost 3 million registered candidates a year (Mark, 2003). The researcher has employed this test in this study in order to explore the development of students' English communicative skill. The students in this study were initially informed regarding the test format and shown the samples of each category of the test before the pre-test begins. They were, then, asked to finish the first part of the test which was listening questions including 100 questions divided into different categories: the photograph, question-responses, conversations, and talks. After the first part has been finished, the examinees were asked to continue finishing the other 100 reading questions contain of the completion, the cloze-test, and the reading passage parts. They have had approximately 75 minutes to have all questions finished. For the posttest, similar procedure has been done at the end of the semester before the scores had been finally analyzed. Though it seems only two domains of the tests were included in the TOEIC test, listening and reading, the study by Donald and Powers (2015) confirmed that the 2300 TOEIC test takers' communication skills results as the target performance domain in their study can be possibly assessed by specific domain not only in that domain but in other related domains as well in a holistic way.

\section{Research Procedure}

The instruction of the course has been given four hours a week divided into two periods for the whole semester. To master the English communication skills, students were required to participate in the Second Life virtual classroom provided by the teacher. The students have been informed earlier about the specific periods for each class by having discussion and agreement among teacher and students. So that the class periods were varied depending on the avalability and the agreement. The class instruction procedures can be clearly seen in Figure 1. 


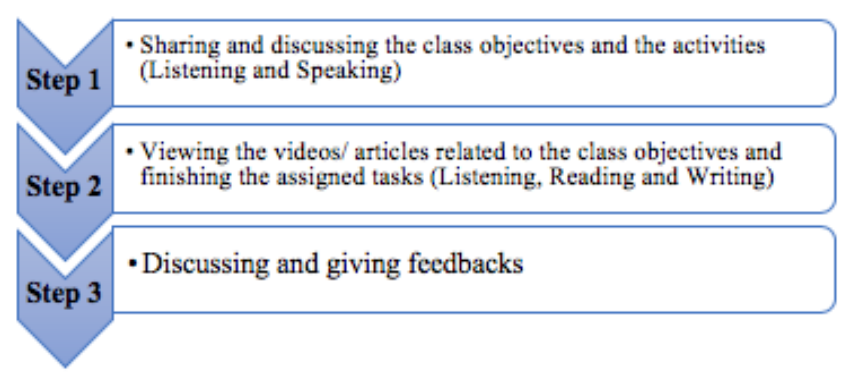

Figure 1. Class instruction procedures

Figure 1. portrays that after the students and the teacher have logged into the Second Life virtual world, the teacher started to inform the class objectives and the tasks going to be assigned for each period. The students were given a chance to ask or discuss about what they are going to participate. For example, students were asked to watch the videos related to some specific topic which was hidden in somewhere around them and they would be asked questions after 15 minute long activity. After the students enjoyed the assigned tasks, the teacher asked the questions related to that videos or articles. It was the time for practicing speaking skill together with writing skill if the teacher asked to write any reflections. The listening practices from enjoying the videos would give them opportunity to develop their listening skill thoroughly. Giving feedbacks for 10 to 15 minutes from the teacher was the last step before the class ended.

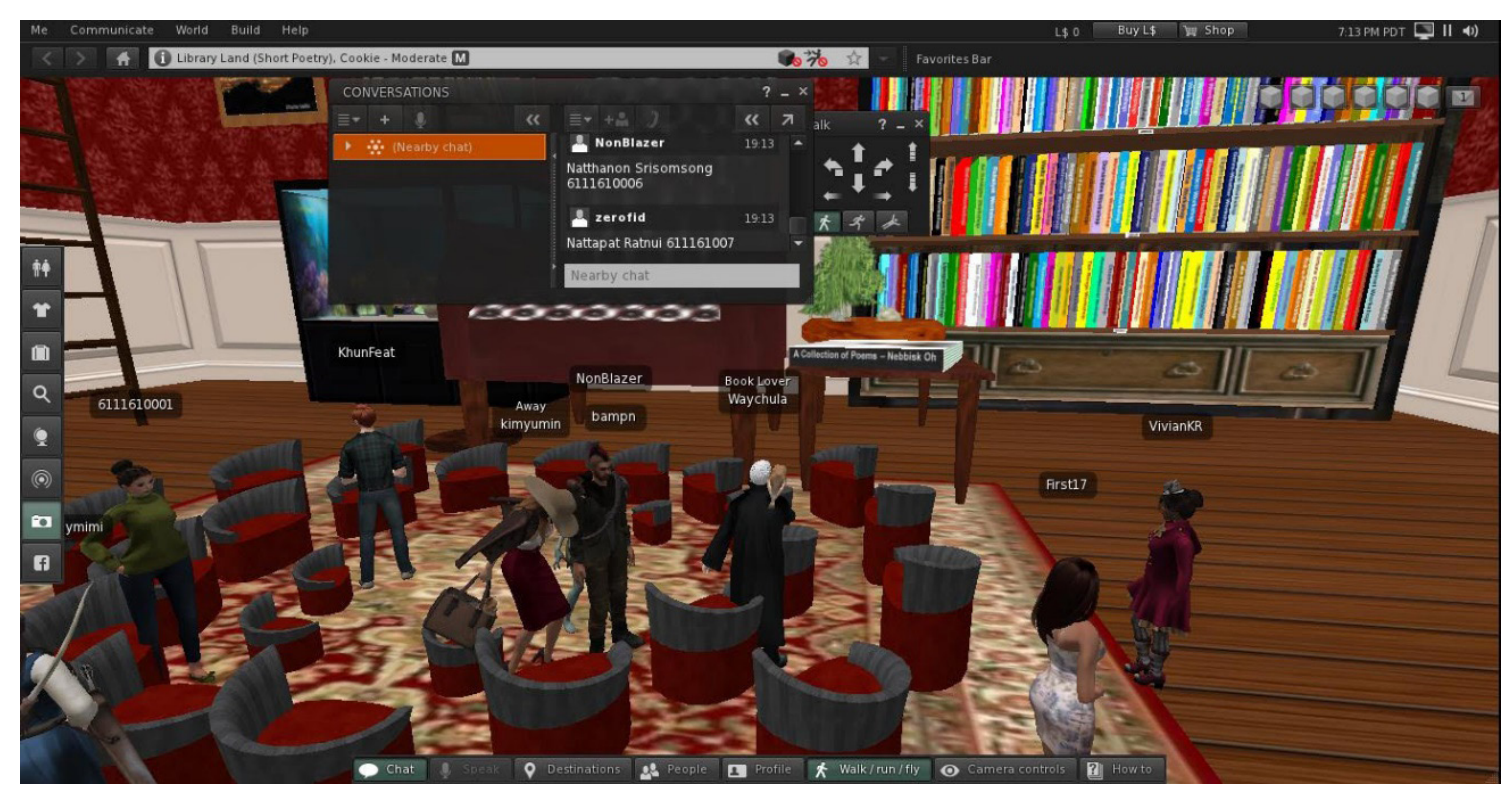

Figure 2. Second life English communication class

\section{Data Analysis}

Though the development of English communication skills were assessed in order to confirm the results of the treatment of the study, other variables such as genders, students' majors of study, and the numbers of hours spent on computers weekly were also monitored in order that the results of the treatments can be a strong evidence to support the research objectives. The data from pre-test and post-test were, then, analyzed by applying the t-test and one-way ANOVA as the results from the $\mathrm{t}$-test itself can show a difference between two groups is unlikely to have occurred because the sample happened to be atypical. This statistical significance is determined by the size of the difference between the group averages, the sample size, and the standard deviations of the groups, and the one-way ANOVA is used to determine whether there are any statistically significant differences between the means of two or more independent (unrelated) groups of variables: male/female, social science/ science, and the numbers of hours spent. The results can affirm if there is any different impact of the different variables on developing students' English communication skills. 


\section{FINDINGS}

Table 1. Descriptive statistic for students' TOEIC scores

\begin{tabular}{cccc}
\hline & TOEIC Scores & Total & Number \\
\hline Variables & Mean & 72.875 & 16 \\
\hline Post_Male & 384.06 & 76.002 & 16 \\
Pre_Male & 318.13 & 78.564 & 24 \\
Post_Female & 403.75 & 75.893 & 24 \\
Pre_Female & 339.79 & 76.990 & 17 \\
Post_Soc & 408.53 & 61.183 & 17 \\
Pre_Soc & 344.41 & 75.610 & 23 \\
Post_Sci & 386.52 & 84.883 & 23 \\
Pre_Soc & 321.30 & 57.949 & 10 \\
Post_5-6hrs & 360.50 & 60.067 & 10 \\
Pre_5-6 hrs & 304.50 & 72.704 & 13 \\
Post_7-9 hrs & 397.69 & 75.301 & 13 \\
Pre_7-9 hrs & 330.77 & 83.936 & 17 \\
Post_20+hrs & 415.29 & 83.555 & 17 \\
Pre_20+hrs & 347.06 & & \\
\hline
\end{tabular}

After all the research methodology has been done, the data collected was analyzed and shown in various categories as follows:

\section{Students' English Communication Skill Development Comparisons}

The following analyzed data have clearly shown the students' English communication skill development in various aspects: the descriptive statistic for students' TOEIC scores, mean scores comparison, descriptive statistic for scores of the post-test, test of homogeneity of variances, and mean score comparison by ANOVA.

The TOEIC scores of the 40 students with different variables are clearly shown in Table 1. All variables of the post-test scores considered in the study were higher than the pre-test ones. In terms of genders, both males and females had higher post-test scores than the pre-test, yet the females achieved better than males $($ Female mean $=403.75$, Male mean $=384.06)$. In addition to the gender variables, the majors of students were counted. Though both social science and science students performed better in the post-test, the students from the social science majors performed better than the students from science (Social science mean $=408.53$, Science mean $=386.52$ ). Another variable counted in the study was the number of hours the students spent on their computers weekly divided into three groups, 5-6 hours, 7-9 hours and 20 hours and more. There was no difference of development in terms of the post-test compared to the pre-test as all groups performed better in the post-test. Interestingly, the higher number they spent weekly, the better scores they performed in the post-test $(5-6$ hrs. $=360.50,7-9$ hrs. $=397.69,20+$ hrs. $=415.29)$. 
Table 2. Mean score comparison (Pre-test and Post-test)

\begin{tabular}{|c|c|c|c|c|c|c|c|c|c|}
\hline & \multirow{3}{*}{$\begin{array}{c}\text { Mean } \\
\text { Difference }\end{array}$} & \multicolumn{4}{|c|}{ Paired Differences } & & \multirow{3}{*}{$t$} & \multirow{3}{*}{$d f$} & \multirow{3}{*}{$\begin{array}{c}\text { Sig. } \\
\text { (2-tailed) }\end{array}$} \\
\hline & & \multirow[t]{2}{*}{ Std. Deviation } & \multirow[t]{2}{*}{$\begin{array}{c}\text { Std. Error } \\
\text { Mean }\end{array}$} & \multicolumn{2}{|c|}{$\begin{array}{l}95 \% \text { Confidence } \\
\text { Interval of the } \\
\text { Difference }\end{array}$} & & & & \\
\hline & & & & Lower & Upper & & & & \\
\hline \multirow{7}{*}{ 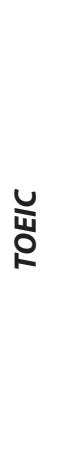 } & $\begin{array}{l}\text { PostMale - } \\
\text { PreMale }\end{array}$ & 65.938 & 39.252 & 9.813 & 45.022 & 86.853 & 6.719 & 15 & .000 \\
\hline & $\begin{array}{l}\text { PostFemale - } \\
\text { PreFemale }\end{array}$ & 63.958 & 41.231 & 8.416 & 46.548 & 81.368 & 7.599 & 23 & .000 \\
\hline & PostSoc-PreSoc & 64.118 & 44.414 & 10.772 & 41.282 & 86.953 & 5.952 & 16 & .000 \\
\hline & PostSci - PreSci & 65.217 & 37.340 & 7.786 & 49.070 & 81.364 & 8.376 & 22 & .000 \\
\hline & Post1 - Pre1 & 56.000 & 33.649 & 10.641 & 31.929 & 80.071 & 5.263 & 9 & .001 \\
\hline & Post2 - Pre2 & 66.923 & 38.217 & 10.600 & 43.828 & 90.018 & 6.314 & 12 & .000 \\
\hline & Post3 - Pre3 & 68.235 & 45.756 & 11.097 & 44.710 & 91.761 & 6.149 & 16 & .000 \\
\hline
\end{tabular}

To be more specific, the paired diferences in Table 2 show the significant data of the pre-test and post-test scores analyzed by applying t-test in all variables. Based on the mean comparison analysis by the use of t-test for dependent sample, it shows that there was significant mean score differences of the pretests and the posttests of the TOEIC tests at .05 level (sig. ranked from 0.000 to 0.001 ). That means all posttest mean scores were greater than all pretest mean scores. All students who have been in the study had significantly improved their English proficiency in terms of communication skill specifically.

Table 3. Descriptive statistic for scores of the Post-test

\begin{tabular}{cccc}
\hline & TOEIC Post-test Scores & & $\begin{array}{c}\text { Total } \\
\text { Number }\end{array}$ \\
\hline Variables & Mean & S.D. & 16 \\
Male & 384.06 & 72.875 & 24 \\
Female & 403.75 & 78.564 & 17 \\
Soc & 408.53 & 76.990 & 23 \\
Sci & 386.52 & 75.610 & 10 \\
5-6 hrs & 360.50 & 57.949 & 13 \\
7-9 hrs & 397.69 & 72.704 & 17 \\
20+hrs & 415.29 & 83.936 & $\mathbf{4 0}$ \\
& Total & & \\
\hline
\end{tabular}

From Table 3, the TOEIC poste-test scores were shown in mean and S.D. of different variables. Even the numbers of female students were higher than males', the mean scores of females were higher than males at 403.75 and 384.06 respectively. In terms of their majors of study, the students from social science majors have performed quite better than the science students with the scores of 408.53 and 386.52 respectively. Interestingly, the students who spent a lot more on computers weekly had the highest scores with the mean of 415.29 compared to other groups who performed lower scores at only 397.67 for the 7 to 9 hours spent a week group, and the least at 360.50 mean scores among the group of spending 5 to 6 hours on computers a week. It can be clearly seen that the higher numbers of hours they spent on computers a week, the better scores they achieved in the TOEIC post-test. 
Table 4. Test of homogeneity of variances

\begin{tabular}{|c|c|c|c|c|c|}
\hline & & Levene Statistic & df1 & df2 & Sig. \\
\hline \multirow{5}{*}{ 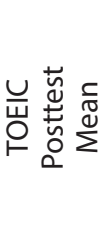 } & Male & .561 & 1 & 38 & .459 \\
\hline & Female & & & & \\
\hline & Soc & .004 & 1 & 38 & .947 \\
\hline & Sci & & & & \\
\hline & $5-6 \mathrm{hrs}$ & 2.186 & 2 & 37 & .127. \\
\hline
\end{tabular}

The table of the test of homogeneity of variances indicated that all variances of the mean scores of TOEIC tests were significantly equal at .05 level which means all the variables shown in Table 4 affirmed that the students performed better in the TOEIC post-test compared to the pre-test ones (Sig ranked from .127 to .947).

Table 5. Mean score comparison by ANOVA

\begin{tabular}{|c|c|c|c|c|c|c|c|}
\hline & \multicolumn{2}{|l|}{ Variables } & \multirow{2}{*}{$\begin{array}{c}\begin{array}{c}\text { Sum of } \\
\text { Squares }\end{array} \\
3720.938\end{array}$} & \multirow{2}{*}{$\frac{d f}{1}$} & \multirow{2}{*}{$\begin{array}{c}\text { Mean Square } \\
3720.938\end{array}$} & \multirow{2}{*}{$\begin{array}{c}\boldsymbol{F} \\
.638\end{array}$} & \multirow{2}{*}{$\begin{array}{l}\text { Sig. } \\
.429\end{array}$} \\
\hline & & Between Groups & & & & & \\
\hline & Male / Female & Within Groups & 221623.438 & 38 & 5832.196 & & \\
\hline & & Total & 225344.375 & 39 & & & \\
\hline \multirow{6}{*}{$\begin{array}{c}\text { TOEIC } \\
\text { Posttest Mean }\end{array}$} & & Between Groups & 4734.401 & 1 & 4734.401 & .815 & .372 \\
\hline & Social / Science & Within Groups & 220609.974 & 38 & 5805.526 & & \\
\hline & & Total & 225344.375 & 39 & & & \\
\hline & & Between Groups & 18967.576 & 2 & 9483.788 & 1.700 & 197 \\
\hline & Hours & Within Groups & 206376.799 & 37 & 5577.751 & & \\
\hline & & Total & 225344.375 & 39 & & & \\
\hline
\end{tabular}

According to the ANOVA table comparing mean scores above, it revealed that there was no significant mean differences of any types of post-test mean scores of different variables: male/female, social science/ science, and the numbers of hours spent at .05 level (Sig. ranked from .197 to .429 respectively). To clarify, students with different backgrounds which were gender, fields of study, and hours of spending the computers have indifferent mean scores in their communication skills.

\section{DISCUSSION AND CONCLUSION}

The findings of the study mentioned earlier have brought various aspects related to the research objectives. The following sections will be discussed regarding the main objective of English communication skill development after applying the Second Life in teaching and learning, the related factors or other variables counted in the study, and how the students in the study found themselves after the semester finished.

\section{Developing English Communication Skills through the Second Life}

In terms of English communication skill development, applying the Second Life in the English language classroom is highly effective as the TOEIC post-test scores of all students in this study with different variables are considered higher than the pre-test ones. Based on the mean comparison analysis by the use of t-test for dependent sample, it showed that there was significant mean score differences of the pretests and the posttests 
of the TOEIC tests at .05 level (sig. ranked from 0.000 to 0.001 ). That means all post-test mean scores were greater than all pretest mean scores. Therefore, all students who have been in the study can be confirmed that they had significantly improved their communication skills. This phenomenon can be affirmed by Hassan, Dzakiria and Idrus (2016) previous similar study. Based on their findings, the Iraqi students' showcase an affirmative response on the potentials of SL in enhancing their English language skills and proficiency through their interaction with the avatar which helped them reduce language anxiety and this making learning English more interesting so that the students' communication skills have been improved. Not only the earlier mentioned study, but Lan and Lin (2016) also confirmed that active involvement play an important role in the success of social communication which suggests that a careful design of learning tests by applying three-dimensional platform like SL was essentially important. In addition, the study done by Wu (2017) also exposed the results in similar direction. To be more specific, the students' skills development has been explored through another technology-enabled tool like SL for enhancing oral English teaching strategies. Using descriptive analysis, her study revealed a positive attitude toward teaching strategies based in SPOC. Because of this development, six teaching strategies were suggested such as text guidance, video demonstration, PPT assisted learning, micro-lecture learning, self-testing and group work. These strategies may further inform the design of the proposed study employing SL framework.

\section{Impacts from Different Variables on Developing English Communication Skills through Second Life}

Though the gender difference was another variable considered if there were any impacts on developing students' English communication skill through the Second Life, the results clearly show that the significant data of the pre-test and post-test scores analyzed by applying t-test in all variables clearly confirmed the students' development based on the mean comparison analysis by the use of t-test for dependent sample. It shows that there was significant mean score differences of the pre-tests and the post-tests of the TOEIC tests at .05 level (sig. ranked from 0.000 to 0.001 ). That means all posttest mean scores were greater than all pretest mean scores. All students who have been in the study had significantly improved their English proficiency in terms of communication skill specifically. The same confirmation has been also confirmed by the previous study done by Bani Hani (2015). The study involved 20 students where five to them were males while the rest were females. The study revealed that students were more competent in utilizing virtual platform devices to read the appointed texts, send questions, read and supply immediate feedback to peers. The study concluded that additional support in that the students' computer self-efficacy and attitudes were essence aspects which influenced the success of virtual learning. It also revealed that gender was not a prime ease which affected the self-efficacy and attitudes toward the virtual learning. In addition to the gender variable, the majors of students were counted. Though both social science and science students performed better in the post-test, the students from the social science majors performed better than the students from science. However, there was no different significance of applying Second Life for developing their English communication skills as the test of homogeneity of variances indicated that all variances of the mean scores of TOEIC tests were significantly equal at .05 level. It can be said that all the variables shown including the variable of the different majors of study affirmed that the students have developed their English communication skills. This phenomenon has been confirmed by the research done by Ince et al. (2014). The research was about developing a 3-dimensional interactive multiuser and multi-admin IUVIRLAB featuring active learning methods and techniques for university students who were from different majors of study and to introduce the virtual laboratory and show its effects on students' attitudes on communication skills and its laboratory. Based on the study, students did not have any technical problems in using the 3-dimensional interactive tool due to their different study fields. It was also noted that students were at ease using the tool and were convenient for learning. The number of hours spent on computers by the students was the last variable considered in this study. Though all the groups have performed better in the post-test compared to the pre-test, the higher number they spent weekly, the better scores they performed in the post-test $(5-6 \mathrm{hrs}$. $=360.50,7-9$ hrs. $=397.69,20+$ hrs. $=415.29$ ). 


\section{CONCLUSIONS}

The result concludes that, based on the findings, Second Life has been found highly effective in developing students' English communication skills. Exploring other variables such as gender differences, the different majors of the study, and the numbers of hours spent by the students on their computers, the paired differences show the significant data of the pre-test and post-test scores analyzed by applying $\mathrm{t}$-test in all variables shows that there was significant mean score differences of the pre-tests and the post-tests of the TOEIC tests. The ANOVA comparing mean scores also revealed that there was no significant mean differences of any types of the post-test mean scores of different variables: male/female, social science/ science, and the numbers of hours spent. To clarify, students with different backgrounds which were gender, fields of study, and hours of spending the computers have indifferent mean scores in their communication skills. It means the students have developed there English communication skill through the Second Life classroom platform.

The present study may be used as a basis in expanding studies such as this kind. It may also serve as a model in implementing virtual-enabled language classes. Despite its positive contributions, limitations of the study concur with Sarac's (2014) work where implementing a Second Life-directed language classroom is expensive and requires logistics such as strong internet connection and a high-performing device. It is also important to have a learning design specialists who are technologically adept in virtual learning tools as their roles will be salient in training teachers in creating contents, designing tasks and activities using other tools of learning.

\section{BIODATA and CONTACT ADDRESSES of AUTHOR}

Hambalee JEHMA is graduated with a B.A. in the Department of English

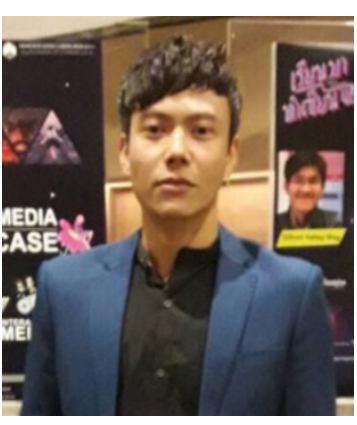
Language and Literature from Thammasat University, Thailand. Upon graduation from Thammasat University, he has pursued his master's degree in Teaching English as a Foreign Language at Thammasat University, Thailand. He is now a PhD candidate (English curriculum in higher education) at Chulalongkorn University, Thailand. He is also working as an Assistant Dean in Research Innovation and Academic Services, and English lecturer at Prince of Songkla University International College, Hatyai Campus, Songkhla, Thailand. His interests are technology in education, second language acquisition (SLA), computer assisted in language learning (CALL), autonomous learning, technology in teaching English, mobile learning (MALL), virtual learning (VL), and Second Life (SL) for language teaching and learning.

\section{Hambalee JEHMA}

Prince of Songkla University International College, Hatyai Campus, Prince of Songkla University, Hatyai Campus.

Address: Prince of Songkla University International College, Hatyai Campus, No.15, $12^{\text {th }}$ Floor LRC2 Building, Kanjanavanij Rd., Kho Hong, Hatyai, Songkhla, 90110, Thailand.

Phone: $+6674289413,+66935833507$

E-mail: hambalee.j@psu.ac.th, jehmahambalee@gmail.com

\section{REFERENCES}

Bainbridge, W. S. (2007). The scientific research potential of virtual worlds. Science, 317 (5837). 472-476.

Baran, B., Cukurbasi, B. Polak, C. \& Dogusoy, B. (2012). Second life users' profiles and views about educational potential of second life: A case of Turkey. The Turkish Online Journal of Educational Technology, 11(4), 253-263.

Braman, J. Vincenti, G. Arboleda, A. Jinman, A (July 2009) Learning Computer Science Fundamentals through Virtual Environments. Online Communities and Social Computing. HCI International Conference. San Diego, CA, USA

Brooks, A. (2016). Teaching language via Second life: The good, the bad, and the future. NYS TESOL Journal, 3(1), 41-46. 
Casner-Lotto, J., \& Barrington, L. (2006). Are They Really Ready to Work? Employers' Perspectives on the Basic Knowledge and Applied Skills of New Entrants to the 21st Century US Workforce. Partnership for 21st Century Skills. 1 Massachusetts Avenue NW Suite 700, Washington, DC 20001.

Chamot, A. U. (1983). Toward a functional ESL curriculum in the elementary school. Tesol Quarterly, $17(3), 459-472$.

Chapman, M. (2003). TOEIC: Tried but undertested. Shiken: JALT Testing \& Evaluation SIG Newsletter, 7(3), 2-7.

Chiang, T.H. C., Yang, S.J. H., Huang, C.S. J., \& Liou, H.-H. (2014). Student motivation and achievement in learning English as a second language using Second Life. Knowledge Management \& E-Learning, 6(1), 1-17.

Couto, S. M. (2011). Second life: Anxiety-free language learning? Proceedings in the International Conference of ICT for Language Learning.

Fetscherin, M. and Lattemann, C. (2008), "User Acceptanceof Virtual Worlds." Journal of Electronic Commerce Research, 9 (3), $231-242$.

Gaukrodger, B. \& Atkins, C. (2013). Second life calling: Language learning communicating across the world. Proceedings in the 30th Ascilite Conference.

Hassan, R. F., Dzakiria, H. \& Idrus, R. M. (2016). Students perception on using second life virtual platform to improve

English Language proficiency. The European Proceedings go Social and Behavioural Sciences.

Hismanoglu, M. (2012). Integrating second life into an EFL classroom: A new dimension in foreign language learning and teaching, International Journal on New Trends in Education and Their Implications, 3(4), 100-111.

Ince, E. et al. (2014). 3-dimensional and interactive Istanbul university virtual laboratory based on active learning methods. Turkish Online Journal of Educational Technology, 13(1), 1-20.

Lan, Y.J. \& Lin, Y. T. (2016). Mobile seamless technology enhanced CSL oral communication. Educational Technology \& Society, 3 (335-350).

Linden Lab. (2009). Second Life [Computer Software]. Available at http://secondlife.com/

Makena Technologies. (2009). There [Computer software]. Available at http://there.com/

Metaversum GmbH. (2009). Twinity [Computer software]. Available at http://twinity.com/

Murphy, J. M. (1991). Oral communication in TESOL: Integrating speaking, listening, and pronunciation. TESOL Quarterly, 25(1), 51-75.

Powers, D. E., \& Powers, A. (2015). The incremental contribution of TOEIC ${ }^{\bullet}$ Listening, Reading, Speaking, and Writing tests to predicting performance on real-life English language tasks. Language Testing, 32(2), 151-167.

The Schome Community (2007), "The schome-NAGTY Teen Second Life Pilot Final Report: A Summary of Key Findings and Lessons Learnt."

Wang, C. X., Calandra, B., Hibbard, S. T. McDowell Lefaiver, M. L. (2012). Learning effects of an experimental EFL program in Second Life. Educational Tech Research Dev, 60, 943-961.

Zamel, V., \& Sheikh-Ibraham, A. L. (1985). Clear Speech: Pronunciation and Listening Comprehension in American English. TESOL Quarterly, 19(3), 585-591.

Zhang, Y. (2009). Reading to Speak: Integrating Oral Communication Skills. In English Teaching Forum (Vol. 47, No. 1, pp. 32-34). US Department of State. Bureau of Educational and Cultural Affairs, Office of English Language Programs, SA-5, 2200 C Street NW 4th Floor, Washington, DC 20037. 